\title{
Environmental Damage in the Criminal Trial of Russia
}

\author{
Alexey Gerasimenko \\ Moscow State University of Civil Engineering \\ Moscow, Russia \\ aleks-gerasimenko@yandex.ru
}

\begin{abstract}
At the present stage of development of Russia, the principle of protection of rights and freedoms of men and citizens is proclaimed as one of the main points that determine the activities of law enforcement agencies. The issue of compensation for harm caused by criminal act is directly related to the efficiency of the activities of the investigation, prosecution and trial. Until now, the subject of scientific debate remains both the definition of environmental damage in the criminal process, and its characteristic features, the ratio of traditional types of harm (physical, material and moral) with environmental harm. The resolution of these disputes is extremely important for determining the category of the victim in a criminal case on environmental crimes, the procedural procedure for filing a civil lawsuit, the possibility of applying other ways to protect the rights of the victim in crimes related to the violation of established norms and rules in the field of environmental safety. Thus, the question of remedying environmental damage has not gotten the limelight in theory and practice yet. This article provides a theoretical model of a procedure ensuring compensation for environmental damage caused by crime.
\end{abstract}

Keywords: harmful consequences of the crime, environmental damage, a way to protect the violated rights, environmental restoration

\section{INTRODUCTION}

At the present stage of development of Russia as one of the main points that determine the activities of law enforcement agencies, was proclaimed the principle of the protection of the rights and freedoms of man and citizen. The issue of compensation for harm caused by criminal act directly related to the efficiency of the activities of the investigation, prosecution and trial. Thus, in theory and practice is incomplete lit question remedying of environmental damage. This article provides a theoretical model provides for a procedure to ensure compensation for environmental damage caused by the crime.

The problem of environmental damage caused by the crime, has been and remains one of the controversial issues of the Russian criminal procedural law. Article 42 of the Code of Criminal Procedure provides for several types of crime consequences: physical, property and moral damage as well as damage to property and business reputation of a legal entity. Art. Art. 247, 250, 251 of the Criminal Code of the Russian
Federation, determines that the result of a criminal act creating a threat of substantial harm to the environment, animal or plant life, contamination or other changes in the natural properties of air.

It should be noted that the quantitative indicators of environmental crimes in Russia vary. Thus, according to statistics, in January - December 2015 recorded 24.74 thousand environmental crime, which is $3.1 \%$ less than in the same period of 2014, however, from January to March 2016 percentages began to grow. For 3 months of 2016 registered 5.14 thousand environmental crime, which is $1.1 \%$ more than in the same period of 2015. [1]

Federal Law of 10.01.2002 number 7-FZ "On Environmental Protection", determines damage to the environment as a negative environment change due to pollution, caused to a degradation of natural ecosystems and the depletion of natural resources. [2]

Until now, the subject of scientific disputes remain the definition of environmental damage in the criminal process, and its characteristics, and the ratio of traditional forms of harm (physical, moral and material) to environmental harm. Dispute resolution data is crucial for determining the category of the victim in the criminal case of environmental crimes, procedural order of civil proceedings, the possibility of using other means of protecting the rights of the victim in crimes related to violation of the established rules and regulations in the field of environmental safety.

\section{METHODS}

To address specific aspects of the problem of environmental damage in the Russian criminal procedural law, it is necessary to define this type of harm. The analysis of this notion is the most complete in the ecological and legal literature. Damage to the environment - is any deterioration of such an environment, which occurred due to violation of certain requirements and the associated any violation of legally protected tangible and intangible benefits, including life and health, property of people and legal entities. [3]It should be noted that this definition does not provide for the possibility of causing moral harm from environmental crime. We can not agree with this, because the physical suffering of man (headache, dyspnea, lacrimation, etc. - according to the 
list given by the Supreme Court of the Russian Federation) [4] received as a result of, for example, water poisoning, air also belong to the category of non-pecuniary damage.

So a crime in the sphere of ecology - there is guilty, the wrongful act that violates the norms of environmental laws and causing damage to the environment and human health. In turn, the harm the environment - it is negative changes of the environment caused by human activities, which have arisen as a result of its pollution, depletion of natural resources, damage to or destruction of ecosystems. [5] Thus, we can determine the environmental damage caused by the criminal offense as the negative changes of the environment caused by environmental pollution, depletion of natural resources, damage to or destruction of the ecological systems of criminal acts that have caused any impairment of tangible and intangible, protected by law assets, for people and companies.

Harmful effects on the environment, in the end, impact on various areas of human life: deteriorating state of health, and as a result, and financial well-being; caused environmental damage can also affect the activity of a legal entity, often compromising financial interests, as well as causing damage to the business reputation (few companies are willing, for example, to open offices and sales outlets in areas with adverse environmental conditions). And here we return to the traditional types of damage taken in the Russian law (the physical, material and moral). Provided for in Article 246 of the Criminal Code adverse consequence as a significant change in radioactivity at operation of commercial nuclear power facilities, may adversely affect the physical condition of the person (change the properties of attention, memory, deterioration of immunity), that is, lead to physical harm, which is expressed in health frustration. Violation of safety rules in construction often entails damage to property: damaged or destroyed buildings, plantations, etc., breaking the rules on handling microbiological and toxic substances can lead to mutations of plants, animals, humans.

\section{RESULTS}

Most often, these harmful effects from the environmental crimes occur indirectly through adverse changes in the environment, but they involve with direct damage to human health and welfare, as well as property and reputation of legal entities. Due to the foregoing, it can be argued that the victim in cases of environmental crimes should be recognized as a natural person to whom an offense under Chapter 26 of the Criminal Code of the Russian Federation, caused material, physical or moral harm, as well as a legal entity, with causing harm to his property and business reputation.

However, the coincidence does not mean that "traditional" forms of harm, adopted in legislation include a damage caused to the environment. Separate the value of environmental damage it manifested in the fact that the negative effects on the environment include a separate category of circumstances, subject to proof in the framework of Part 1. Art. 73 Code of Criminal Procedure. However, many scientists studying the problems of environmental damage, talk about the difficulties encountered in proving these circumstances. The greatest difficulty associated with the establishment of a causal link between the act and harmful consequences, moreover, often exacerbated by a long time interval elapsed since the commission of the crime. In addition, the investigator does not possess special knowledge in the field of ecology and forced to engage experts for their conclusion. [6]

The fact of infliction environmental damage is important for determining the cause of dangerous chronic diseases at causing physical harm, establishing the degree of moral suffering when causing moral harm. Environmental crimes are devastating to human health and life, but such crimes as the damage of the earth, air pollution, water pollution and the marine environment entail harmful effects of having a purely ecological character.

Recovery methods the violated rights of the victim are dictated by the specificity of the damage caused to the environment. The Criminal Procedure Code as the primary means of compensation for harm caused by the offense, provides for a civil suit. The essence of a civil action, when it applied as a tool to compensate for environmental damage should be considered comprehensively. On the one hand, this is a claim for damages, On the one hand, this is a claim for damages, stated by person to whom an offense has been caused some damage through adverse environmental change.

This requirement applies to state bodies, leading the process, and permitted by the court, together with the announcement of the verdict in the criminal case. This reflects the unity of the material content of the civil lawsuit and procedural forms of realization of the stated requirements. On the other hand, a civil action is only a procedural document by which fix the fact of the victim statements. Until recently, when considering the material side of the civil suit, traditionally it was thought that this type of action in criminal proceedings is a form of compensation for property damage only. Legislation in support of this, throughout the existence of the institute civil action, contained a provision on the possibility to claim compensation only material damage.

Losses, expressed in the damage or loss of property, easy enough to quantify, and the calculation of compensation. Therefore, to talk about the exact calculation is possible only with respect to property damage. The size of the other types of harm, including environmental, largely depends on the value judgments of the investigating authorities and the court. The main problem is the absence in the legislation accurate and specific criteria for assessing the environmental damage. The presence of the subjective factor in the determination of these criteria, gives rise to a certain difference in the calculation of compensation. We should proceed from the fact that the set upper and lower limits of monetary compensation, but the court within those boundaries defines a specific amount of payments taking into account the specificity of each environmental crime and the degree of harm to the environment. Thus, there is the expansion of the boundaries of the application of the civil action in criminal proceedings. We see that this tool can be used both in terms of property damage, and in relation to environmental damage.

It should also be noted that legislative acts regulating relations in the sphere of environmental protection, provides for a wide range of methods of redress. This is due to the 
Since the UN Stockholm conference on the human environment (1972), European and American environmental law has been a much more sophisticated legal institution. In the legal systems of Western countries, the types of environmental harm are clearly differentiated into:

- guilty of causing harm;

- infliction of harm;

- forced infliction of harm, which is lawful. [10]

Norms of the European legislation assume unconditional responsibility of the producer and the owner of a source of the increased ecological danger, and also specify in detail mechanisms of compensation of harm. In particular, in addition to restitution and voluntary compensation for harm, liability insurance mechanisms, collateral instruments are provided, for example, the introduction of a significant amount of money into a Bank account, guaranteeing reimbursement to victims in case of negative consequences. In Anglo-American law, the institution of unconditional liability applies if damage is caused to property [16].

In addition, the system of European legislative measures for the protection of the environment includes:

- setting environmental quality standards;

- assessment of the impact of the planned activities on the environment;

- setting standards and permitting procedures for pollutant emissions;

- preliminary planning of environmental protection activities by each potentially hazardous production.

The main form of protection of environmental rights of citizens is a claim for non-compliance with environmental legislation. Criminal liability is regulated by both environmental legislation and criminal codes.

In most European countries (the UK, the Netherlands, Sweden, France) [13] and the United States, it is possible to apply to the court for the protection of their environmental rights of any interested person. In Germany [17] , judicial protection is possible only in case of violation of the individual rights of the plaintiff, in Italy and Greece the right to appeal to the court is vested with specialized associations.

Based on the above, it can be concluded that the environmental damage caused by the crime, from the point of view of proof, is an independent kind of harm in the criminal process. Consequently, the finding of its existence as well as the extent and nature directly affects the compensation for harm to victims and restoration of the environment. As a basis for the recognition of victims environmental harm acts indirectly, through traditional forms of harm: physical, material and moral. In addition, the procedure for compensation of damage to the environment, methods and forms of reimbursement is provided for by special regulations vary widely.

In acts of Russian and European legislation, a distinction is made between environmental damage and harm of ecology. In 
of Envirionmental Economics and Management" 2005, nr. 38S.1119.203

this case, the concepts of harm and damage are used as synonyms. The analysis of legal norms indicates the need for introducing contamination of the concepts of environmental harm, environmental damage, violation of environmental safety.

With the relative development of Russian environmental legislation, it should be noted the backwardness of the domestic environmental legal system, which does not provide effective environmental protection. This is due to the failure of all subjects formal requirements of the legislation. In the consciousness of society, and especially in the business environment, environmental and legal problems do not occupy a worthy place and retreat before the issues of profit-making by any means. Environmental harm is mostly denied or met with indifference.

\section{REFERENCES}

[1] The state of crime in Russia - official site of the Ministry of Internal Affairs of the Russian Federation. [Http://www.mvd.ru];

[2] Federal Law of 10.01.2002 number 7-FZ "On Environmental Protection" (as amended on 24.11.2014 as amended on 12.29.2014..);

[3] Brinchuk MM Environmental Law: Textbook for higher educational institutions. - M., 2015.

[4] Some questions of application of the law on compensation for nonpecuniary damage: Resolution of the Plenum of the Supreme Court on December 20, 1994 №10 // [http://www.base.consultant.ru]

[5] Guidelines for the assessment and compensation of damage caused to the environment as a result of environmental offenses. Approved by the State Committee on Ecology of the Russian Federation 06.09.2017.

[6] Savichenko IA Initiation of criminal cases on environmental crimes // Fundamental and applied problems of crime investigation management M .: Academy of Management MVD of Russia, 2005.

[7] Declaration of Basic Principles of Justice for Victims of Crime and Abuse of Power. Adopted by the UN General Assembly resolution 40/34 29.11.1985 // [http://www.un.org].

[8] Albertini A., Austin D.H., Strict Liability as a Deterrent in Toxic Waste management: Empirical Evidence from Accident and Spill Data,"Journal
[9] Arcuri A., Controlling environmental risk in Europe: the complementary role of an EC. Environmental liability regime, "Tijdschriftvoor Milieuaanspraklelijkheid", 2010.

[10] Bender B., Sparwasser R., Engel R. Environmental law. Fundamentals of public environmental protection law. 3 ed. Heidelberg: C.F.Muller. 2015.- 658S.

[11] Beyer Peter. A new dimension of environmental liability in Europe? An analysis of the European directive on environmental liability. Environmental Law Journal. Nomos. 2018.№76. S.257-265.

[12] Bergkamp L., The proposed EC Environmental Liability Regime and EC Law Principles. "Environmental Liability Law Review" 2001.№ 11 S.251-266;

[13] Boyle A.E, Globalising Environmental Liability: National and International Law, "Journal of Environmental Law". 2016.vol.17.

[14] Dhondt Nele. Integration of Environmental Protection into other EC Policies.Legal Theory and Practice. Gronongen: Europa Law Publishing.2003.

[15] Drame L, Recovering damage to the Environment par se Following on Oil Spill: the Shadows and Lights of the Civil Liability and FundConventions of 1992, "Rewie of European Comminity and International Environmental Law" 2014. Vol. 13. -386 S.

[16] Lomborg B., The Sceptical Environmentalist: The Real State of the

[17] Potthast Thomas (ed.) Ecological Damage - Conceptual, Methodological and Ethical Aspects, Series "Theory and Ecology" Volume 10. Frankfurt am Main: Peter Lang Verl. 2016. - 341 S.

[18] Verschuuren Jonathan, Principles of Environmental Law. The Ideal of Sustainable Development and the Role of Principles of Baden: Nomos.2003.

[19] Wagenbauur Rolf. EU Commission submits proposal to create ecoliability. // Journal for Legal Policy. 2017. S.142-143.

[20] Wilde M.L., The EC Commission's White Paper on Environmental 1.iability: Issues and Implications. "Journal of Environmental Law", 2011;

[21] Winter Gerd, Risk Assessment and Risk Management of Toxic Chemicals in the European Community.Badeb-Baden:Nomos. 2000. $261 \mathrm{~S}$.

[22] Winter Gerd. German Environmental Law. Basic Texts and Introduction Dordrecht-Boston-London: Martinus Nijhoffi'Grahami\&Trotman. 2015 Environment, Cambridge 2014. International,European, and National Environmental Law. Baden- 